\title{
Preservation of Local Culture Wisdom Values of Kean Santang Wawacan in Ancient Sundanese Text: A Filological and Ethnopedagogical Study
}

\author{
D Koswara ${ }^{1}$, R Permana ${ }^{2}$, P Hyangsewu ${ }^{3}$ \\ \{ ${ }^{1}$ dedi.koswara@upi.edu, ${ }^{2}$ ruswendi.permana@upi.edu, ${ }^{3}$ pandu.hyangsewu @upi.edu \} \\ 1,2,3 Universitas Pendidikan Indonesia Bandung, Indonesia
}

\begin{abstract}
This research entitled " Preservation of Local Culture Wisdom Values of Kean Santang wawacan in Ancient Sundanese Text: A Philological and Ethnopedagogical study". The purpose of this study is (1) to describe and transliterate Kean Santang wawacan script from Arabic-Pegon into Latin letters, (2) to describe the formal structure and narrative structure of Kean Santang Wawacan, and (3) to describe the ethno-pedagogical values contained in Kean Santang wawacan script. The method employed in this study is the study of philology to transliterate ancient Sundanese script from Arabic-Pegon into Latin script, as one of technology transfer effort from traditional work pattern to modern technology. Therefore, the descriptive and transliteration techniques are applied. The literature study is used to understand the elements of Kean Santang wawacan story covering themes and problems, story facts (plot, character, background) and story devices (title, point of view, style, and tone) contained in this ancient Sundanese script. This research collaborated three approaches, namely philology approach, literary approach, and ethno-pedagogical approach. Philological research findings revealed the following facts: (a) Kean Santang wawacan writer is not always consistent in writing letters, lack of understanding about the rules of making pupuh; the use of punctuation in the text studied is not homogeneous, especially the punctuation for pupuh alteration; while based on the results of literary research it is shown that Kean Santang wawacan has a formal and narrative structure as commonly it required. Based on philological and literary research findings it is known that Kean Santang wawacan contains values of local cultural wisdom education (ethno-pedagogy) related to the purpose of life and postulate of Sundanese people i.e.hirup bagja, aman, tingtrim ngahenangngahening, luhur darajat, ngeunah angen-ngeunah angeun, sampurna dunya aherat. Hurip waras, cageur bageur, bener, pinter, jujur, ludeung, silih asih, silih asuh, silih asah, sinegertengah. Briefly, these views are implied in the phrase: glory, happiness, serenity and tranquillity, freedom, peace, salvation, perfection, healthy life, rightful, smart, honest, brave, loving, caring, intellectual, and proportional.
\end{abstract}

Keywords: Wawacan, Philology, Ethnopedagogy 


\section{INTRODUCTION}

In classical Sundanese literature there is a script that has local history value called wawacan. Wawacan is more commonly known as babad. This Sundanese literature of local history genre is limited in number compared with other types of wawacan. Based on Sundanese manuscripts catalog it is known that there are only 4 pieces of manuscripts that located in Garut, Majalengka, Ciamis, and Bandung [1]. Among several numbers of wawacan that have local historical value and reflect the concept of the nation's mental revolution at that period is Kean Sangtang wawacan. The contents illustrate the characteristics of Prabu Siliwangi's son, a charismatic figure of Sunda Pakuan Pajajaran Kingdom. His name is Kean Santang. His name is preserved in a script entitled Kean Santang wawacan. This wawacan script becomes one of the monumental works for the history of Sundanese literature. However, until now Kean Santang has remained an idol and role model for the Sundanese people because he is considered a leader who is authoritative, fair, wise, and affectionate to his people. He is a prominent figure of Islam and founder of today West Java city. This figure has been preserved into a fictional and factual work in Sundanese literary history in the form of wawacan. Wawacan is a story in dangding form, written in pupuh. The text of wawacan is narrative, generally long narrative; often pupuh alteration usually accompanying the episode shift. Wawacan is usually read by way of being sung or developed in performance of beluk art (Java: macapatan), but not all wawacan story can be performed in beluk art [2]. Wawacan script is generally handwritten (hand script; manuscript). The original form was written in the Cacarakan Java letters and some were in Arabic-Pegon letters. In relation to the notion of wawacan, Rosidi ([2]) explains that wawacan is a saga written in the form of a particular poem called dangding. Dangding is a certain fixed words connection to describe certain phenomena. Dangding consists of several pieces of poetry called pupuh. The famous pupuh commonly used in wawacan are dangdanggula, sinom, kinanti, asmarandana, magatru, mijil, pangkur, durma, pucung, maskumambang, wirangrong, balakbak, and others of which are 17 kinds.

This wawacan literary was born around the $17^{\text {th }}$ century. Based on the information the infiltration of pupuh form that bear wawacan was derived from the Javanese literature that penetrated sometime in the 17 th century (Rusyana in [2]). Initially the spread of wawacan was done through handwritten duplication. Some of them were written in cacarakan (Sunda-Java script). According to Kartini ([3]), at the beginning of its development wawacan was disseminated through moslem scholars in Islamic schools. This can be seen from the many contents of wawacan, whether in the form of a manuscript or already printed, containing the teachings of Islam and Islamic stories, both in adaptation and original form. In subsequent developments wawacan also spread through the aristocratic and blue blooded Sundanese people such as regents, demangs, and officials under it, including Islamic officials, such as penghulu and kalipah. Generally wawacan coming from pesantren was written in Arabic or Pegon, while wawacan composed by regents or Sundanese nobles was written in Sundanese-Javanese letters. Furthermore, after the literacy culture in Latin letters spread through schools established by the Dutch government, wawacan was written and printed in Latin letters. Sometimes the Dutch government's statements were printed in two letters, Java-Sunda and Latin. For example wawacan Budayatussalik adapted by R. Demang Bratadiwidjaja was printed by Lands Drukkery in 1864. The literary works of wawacan form flourished in the late nineteenth century until mid-twentieth century. In general the literary work of this wawacan form has a fixed structure element, namely manggalasastra (allophone), content, and closure or colophon. Manggalasastra usually contains a request for a permit and forgiveness to the Creator or karuhun, as well as an apology for the authors 'or the authors' incapability. Colophon is present 
at the end of the story which generally contains date or time of the writing or copying, accompanied by an apology from the author or copyist of any deficiencies. Usually in this section the author or copyist likes to humble themselves.

In general, the contents of wawacan story was derived from Islamic literature and Javanese literature, fairy tales and saga, pantun stories, babad, and stories derived from life in the society. In addition, the content of wawacan stories can also be classified by its type, i.e. religious, rules/laws, societies, mythology, education, literature, historical literature, and history.

One of wawacan stories that describe local history literature of the founding of Cirebon kingdom is Kean Santang wawacan. The contents of this wawacan have an intertextual relationship with Kean Santang wawacan. Both names of the characters used as story titles are King Siliwangi's sons, The King of Pajajaran Kingdom, but of different versions. The contents of Walangsungsang wawacan are closer to local factual history values, even if they are fictional. On the contrary, the content of Kean Santang wawacan story has many fictional values rather than factual. Of course both are equally classified into local history literature and contain values of local cultural wisdom for Sundanese people at that time. These two princes of King Pajajaran have the same vision and mission to spread Islam, but in different periods of time and places. The existence of the factual and fictional levels of these two figures at that time can be seen in the span of the connecting line of Sundanese history. Therefore an intertextual study with other texts containing Sundanese history or Sundanese historical literature, such as Sundanese historical books written by Saleh Danasasmita and Yoseph Iskandar, and Sundanese historical novels of Yoseph Iskandar as a comparable data source or its secondary data is required.

This research will try to answer the following research questions:

1. How to transliterate Kean Santang wawacan script from Arabic-Pegon into Latin letters?

2. How does the story structure cover themes and problems, story facts (plot, characterization, and background) and story devices (title, point of view, style and tone) in the Kean Santang wawacan script?

3. What are the values of ethno-pedagogy contained in Kean Santang wawacan script?

Based on the above research problems, the objectives of this study are aimed to:

1) describe and transliterate Kean Santang wawacan script from Arabic-Pegon into Latin letters,

2) describe the structure of the story covering themes and problems, story facts (plot, characterization, and background) and story devices (title, point of view, style and tone) of Kean Santang wawacan script,

3) describe ethno-pedagogy values of Kean Santang wawacan script.

The results of this research can be used for the study of literature, linguistics, and sociology. From ethno-pedagogy side, Kean Santang wawacan text can be used as a comparative reference of mental revolution and documents of local cultural wisdom values as well as nation character education for Sundanese ethnicity and the Indonesian people in general.

This study needs at least three theories, namely the theory of philology, literature and ethnopedagogy. Philology relates to the technique of manuscript description, transliteration and text translation. In describing the manuscript the writer employed Pigeaud theory [4] in Literature of Java, and Ekadjati [1] in Sundanese script: Inventarisasi dan Pencatatan. While for transliteration of manuscript the writer employed the theory of Baried, et al. [5] in Pengantar Teori Filologi, and Ekadjati [6] in Cerita Dipati Ukur: Karya Sastra Sejarah Sunda. Furthermore, in translation techniques the writer employed Partini Sardjono's theory [7] in Pengkajian Sastra.

To understand the values of nation character education (ethno-pedagogy) contained in Kean Santang wawacan script, it is necessary to use Robert Stanton literary theory [8]. In principle 
he argues that the literary work is composed of an autonomous structure. The structure consists of (1) story theme, (2) story facts (plot, character, and character, background, and (3) story devices (title, point of view, style, and tone).

The main theory of this structure is literary approach. Therefore, as a fundamental support of this research the writer applied literary approach proposed by Abrams as quoted by Teeuw [9] and Partini Sardjono [7].

The ethno-pedagogy theory used in this research is the concept of nation character education proposed by (1) Suwarsih Warnaen, et al. [10] regarding the purpose of life and postulate of the Sundanese people such as hirup bagja, aman, tingtrim, ngaehang ngaheing, luhur darajat, ngeunah angen ngeunah angeun, sampurna dunia akherat. Hurip waras, cageur bageur, bener, pinter, jujur, ludeung, silih asih, silih asuh, silih asah, sinegertengah. This view of life is briefly implied in the phrase: glory, happiness, tranquility and serenity, freedom, peace, salvation and perfection. (2). Muslich theory [11] which divides character education values into nine pillars: love of God and all His creation, independence and responsibility, honesty or trustworthy and wise, respectful and polite, generous, helpful and mutual cooperation, confident, creative and hardworking, leadership and justice, amiable and humble, and tolerance, peace and unity.

Confidently Lickona ([12]) emphasized the importance of the three components of a good character, morale knowing, moral feeling, and moral action. It is necessary to educate Indonesian citizens (children, students, and youth) to understand, to feel, and at the same time implement good values.

\section{RESEARCH METHOD}

The philology research approach used in this research is the approach related to manuscript research method, descriptive technique and manuscript transliteration. The manuscript research method used in this research are plural textual research method, Working Principle Grounding Method (legger), while the research technique is transliteration technique and manuscript translation.

The literary approach used in this study is an objective approach with structural methods. Structural method is intended to understand the elements of (story structure) Kean Santang wawacan story which includes: theme, plot, character and characterization, story background, and the relationship of elements functions amongst. The result of structural analysis of Kean Santang wawacan form and contents will be described qualitatively so that it can give meaning to a generalization related to the values of nation character education. Therefore, in general, research method used in this research is descriptive-qualitative method.

The research techniques employed in this research are literature study, field study, transliteration technique, and analysis technique. The literature study technique and field study were conducted in various libraries and museums as well as individual and institutions manuscripts collections in West Java to obtain the script of Kean Santang wawacan.

Analytical techniques were employed to describe the origin, size, contents and function of the text philologically. The transliteration technique was utilized to transliterate Kean Santang wawacan text written in Arabic-Pegon into Latin letters. Furthermore, Kean Santang wawacan story structure analysis is based on literary and ethno-pedagogical studies.

Primary data of this research based on literature study from Sundanese manuscript catalog [1]. There are four Kean Santang wawacan manuscripts, which belonged to individual collection in Garut regency, Ciamis regency, Bandung regency, and Majalengka regency. In addition, the secondary data used in this research sourced from Sundanese history and Sundanese historical novels by Yoseph Iskandar i.e. (1) Pamanahrasa [13]; (2) Putri 
Subanglarang [14]; (3) Prabu Anom Jayadewata [15]; and (4) Tri Tangtu di Bumi [16]; Ancient Sundanese manuscripts i.e. Carita Parahyangan, 1991 and Carita Ratu Pakuan. Added together with Sundanese history book written by Saleh Danasasmita i.e. Nyukcruk Sajarah Prabu Siliwangi jeung Pakuan Pajajaran, Mencari Gerbang Pakuan [17], Menemukan Kerajaan Sunda [18], Senopati Balangantrang: Intrik jeung Barebedan Pulitik di Galuh, and Yoseph Iskandar's Sundanese history book entitled Sejarah Jawa Barat (Yuganing Rajakawasa) [19].

\section{RESULTS AND DISCUSSION}

Wawacan literary works are constructed by formal structure and narrative structure. The formal structure is essays presentation form by means of pupuh poems. In addition, wawacan formal structure is also characterized by the presence of manggalasastra (allophones) at the beginning of the story. While the meaning of the narrative structure in wawacan story structure is formed from the interconnected story elements of the whole story and its coherence. Those story elements are the theme, plot, character, characterization and story setting [20].

In addition to the formal structure, Kean Santang wawacan is also characterized by the presence of manggalasastra and colophon. Manggalasastra of Kean Santang wawacan is at the beginning of the story that formed in Dangdanggula pupuh poems with 7 stanzas. The contents are the praise of the author to Allah SWT, Prophet Muhammad Saw., The Companions, and the writer's apology to the reader because of his writing inadequacy. While Kean Santang wawacan colophon is positioned at the end of the story and formed in dangdanggula pupuh with 2 stanzas. The content tells that the story has been ended and the writer apologizes for his writing inadequacy.

In relation to the narrative structure of Kean Santang Wawacan, it can be described as follows. The main theme of Kean Santang wawacan is the Islamization of Sundanese society in Pajajaran Kingdom territory, especially in Garut region by Kean Santang. This Islamization was rejected by King Pajajaran, namely King Siliwangi (his father) who insisted on maintaining his belief in the Sunda Wiwitan religion and was hostile to Islam. In other ancient Sundanese manuscripts, such as the Kean Santang wawacan script, the rejection was done passively, that was, King Siliwangi went away from Pajajaran Kingdom by doing moksa (ngahyang). He escaped from Kean Santang (his son) pursuit who wanted to Islamize him. This is different from historical source information which notifies that Jayadewata or Pamanahrasa who later held Sri Baduga Maharaja or Prabu Siliwangi was very tolerant to the existence of other religions in Pajajaran, including Hinduism, Buddhism, and Islam. Indeed he did not embrace Islam, but his wife, Nyai Subanglarang and his son from Subanglarang (Walangsungsang, Rarasantang, Raja Sangara) were Muslims. This religious tolerance in Pasundan land had long been instilled by his grandfather, King Niskala Wastu Kancana, when he became a king in Sunda Galuh Kingdom. (See Sejarah Jawa Barat: Yuganing Rajakawasa and History Novel: Prabu Wangisutah, Pamanahrasa, Prabu Anom Jayadewata, Tri Tangtu di Bumi by Yoseph Iskandar). There was a harmonious religious life in Pasundan land. They work together to build Pajajaran Kingdom even with different religious beliefs. Thus, the main issue that supports the story theme in Kean Santang wawacan is actually the need to reform the religious belief system from Hinduism to Islam.

The storyline in Wawacan Kean Santang (WK) can be discussed as follows. Kean Santang, the supernatural figure left the Pajajaran Palace to look for his rival, namely King Ali in Mecca on the instructions of Angel Jibril who disguised himself as a fortune-teller --- Before going to Mecca Kean Santang first meditated at Cadas Ngampar, Ujung Kulon Banten - In his meeting he got clues and magical powers to get to Mecca to meet His Majesty Ali --- Kean Santang went 
to Mecca by road, sea, through the earth, and flew in the sky. Suddenly Kean Santang emerged from the bowels of the earth in Saudi Arabia --- At that time in Mecca Rasululloh and his companions had gathered to establish the Mosque of Harom. However, they were still waiting for Ali to receive the task of lifting the mosque's huge pillar. But Ali, who was going to leave early in the morning, was told by Gabriel to wait for his first guest from Java to meet him. - For a moment Ali waited, but his guest had not yet arrived. So he went down from his house to meet Rasululloh. In the middle of the road suddenly a stranger called him. The person asked for the address of Your Majesty Ali. He was shocked because everyone in Mecca knew him. It turned out that the person who called it was a guest from West Java, Indonesia named Kean Santang. Kean Santang introduced himself to His Majesty Ali with an arrogant attitude, feeling to be the most powerful person in Java. He conveyed the intention of his arrival to Mecca, which was to try out the power of the Majesty of Ali. His Majesty Ali invited Kean Santang to meet someone he challenged before Rasululloh. Before walking, Majesty Ali sticks his stick (iteuk) then continues to walk with the guest. After traveling a bit further, Sire Ali pretended to forget that his stick was left in their original meeting place. Kean Santang immediately ran like lightning towards Ali's stick. He was unable to take the stick that was stuck until it released fresh blood from the skin pores all over his body. Finally he lost all his magic, drooping limply, helpless. Then King Ali approached the helpless Kean Santang. Then read basmalah and sahadat, then rubbed on Kean Santang. So Kean Santang recovered at a time. Kean Santang was shocked by the knowledge possessed by the person in front of him. In his heart murmuring, "truly this person is powerful, how should I face the famous Bagenda Ali later?" Both of them continued walking towards Harom's mosque. Both arrived at the Harom Mosque. Rasululloh called His Majesty Ali and asked about the delay in coming to the Harom Mosque. Kean Santang was shocked, he only found out that the person who was with him was his Majesty Ali whom he had been looking for. Then His Majesty Ali explained to Rasululloh that he was waiting for the powerful guest from Java who came with him. Furthermore Rasululloh tested the magic of Kean Santang to lift one of the pillars of the Harom mosque which was supposed to be for the task of His Majesty Ali. Apparently Kean Santang was humiliated, all his strength was destroyed before Rasululloh. He was unable to lift the pillar of the Harom mosque. Since then Kean Santang declared Islam and he was given the task by Rasululloh to Islamize Java in Indonesia --- Kean Santang returned from Mecca by riding a Semprani Horse that could fly, he was given by Rasululloh a chest filled with Meccan land, hours of water and letter from Rasululloh. On the way back, he passed Sumatra, Kerawang, and Cirebon. In Kerawang land and jamjam water was spilled --- it was predicted that later in that place there would be a pesantren called Syech Quro. Likewise, at the top of the Cirebon Amparan Jati Mountain, the land and the jamjam water spilled too, so it was predicted that in this place there would be a pesantren with the name Syech Sunan Gunung Jati boarding school. From this place Semprani Horse continued to fly until he arrived at the peak of the Holy Mountain of Garut. The horse is loud and down in this place. All land and hourly water spilled in this place. Semprani's horse immediately disappeared. Then Kean Santang opened the letter, it turned out that it contained an assignment from Rasululloh that in that place he must stay and dwell forever --- So from this place he began to spread the religion of Islam. The first person he wanted to convert was his own father, Prabu Siliwangi as the maharaja of the Kingdom of Pajajaran. His father refused and avoided the Santan Kean by means of the moksa (ngahyang) leaving the Pajajaran Palace, going to the Sancang region, Morocco, Pameungpeuk Garut with his followers. This place was posted as Prabu Siliwangi's new stopover with followers who had transformed into Sancang tigers. While Kean Santang resides in the Peak of Holy Mountain which is now called Godog, the eastern part of the city of Garut. His tomb was sacred to this day. 
The relationship among plots in Kean Santang wawacan is a causal relationship, a logical relationship, but with an axiom that Raden Kean Santang has an extraordinary powers compared with ordinary human being. He did not use his supernatural powers for arrogance and malignity, but to help others. In other words Kean Santang departure from Pajajaran Palace can be interpreted as a sacred journey to mentally evolve shifted from the doctrine before Islam into the Islamic belief that blessed by Allah Swt.

Based on its structural study it is known that Kean Santang wawacan text is loaded with nation character education values (ethno-pedagogy) embedded in the local cultural wisdom values of the Sundanese society that day. The value of ethno-pedagogy is related to the Sundanese views of life i.e. (1) the view of human life with himself based on the following parameters (a) Intellectual Quotient (IQ), well educated, (b) Emotional Quotient (EQ), good cultural knowledge, (c) Spiritual Quotient (SQ), religious, (d) Actional Quotient (AQ), skillful, (2) the view of human life to the environment which is exposed to activities in three life dimensions i.e. the family, the community, and the nation based on the concept of trisilas (silih asih, silih asuh, silih asah: love, care and advice),(3) the view of human life with nature which is characterized by the consciousness of ecology and geopolitics of every human being to maintain and preserve their natural environment for the benefits of human being, (4) the view human life with Allah SWT. This is manifested by strong human conviction to Allah Swt, as the creator of earth, sky, human beings, with all its contents. Humans have an obligation to practice the Islam shari'a brought by messenger of Allah, the Prophet Muhammad, (5) the view of human life in pursuing physical affluence and inner satisfaction. This is reflected in the text of Kean Santang wawacan through the character of Kean Santang who has an awareness of ethical, aesthetic, fair, honest, trustworthy and amiable in carrying out his role as a religious and government leader of his day in Garut.

\section{CONCLUSIONS}

There are several findings obtained in Kean Santang wawacan script research which is described as follows. The author/copy writer of Kean Santang wawacan is not always consistent in writing the letter. The author/copy writer of Kean Santang wawacan is insufficient to understand the rules of making pupuh poems. The use of punctuation in the Kean Santang wawacan text is not homogeneous, especially the use of punctuation for pupuh alteration. In terms story content, Kean Santang wawacan is classified as literature genre. It has a formal and narrative structure as commonly wawacan required. The use of Arabic-Pegon in Kean Santang wawacan script expressed the impression of the existence of local cultural wisdom values in the community at that period, especially for the script writer and community user.

The tradition and transmission of wawacan texts in the past is aligned with the development of local cultural wisdom values of the community in accepting and spreading Islamic shari'ah in its time through wawacan. Besides functioning as an Islamic syiar, in the past, Kean Santang wawacan also served as an entertainment for the people who performed the sacred rituals called beluk. But now the sacred ceremony and ritual is rarely found because its function has shifted into entertainment art only. The society's reception of wawacan script in the past is one of the evidence of the existences of local cultural wisdom values of Sundanese society at that time which is rarely found nowadays.

The creativity result of writing and copying Kean Santang wawacan and community reception are the characteristics of local cultural wisdom values of Sundanese society existence at that time that now has disappeared. Based on the results of the description and identification of the manuscript it can be assumed that Kean Santang wawacan text belongs to old manuscripts 
category. It is identified from the old European paper (striped shadow) and the text writing (punctuation) that used violet ink. Therefore Kean Santang wawacan text is predicted to be used in the late of $18^{\text {th }}$ century.

Kean Santang wawacan manuscript was written in Arabic-Pegon. This indicates that wawacan writing workplace (scriptorium) was at pesantren. The manuscript was not written by Sundanese nobility which is generally written in Java-Sunda script (Cacarakan). Based on the results of Kean Santang wawacan manuscript transliteration, there are two consonant clusters which cannot be used to write words beginning with letters / dr /, / pr /, / sr /.

Kean Santang wawacan manuscript has both formal and narrative structure. Its formal structure is constructed by manggalasastra presence and colophon which is formed in pupuh poems completed by sasmitaning pupuh. While Kean Santang wawacan narrative structure embodied in the theme, plot, character and characterization, the background and values. The theme revolved around Islamic syiar and the spreader of Islam in West Java. The plot includes progressive plot with loose type quality plot. Nevertheless, the three constituent elements such as conflicts, imagery, and delays remain present in Kean Santang wawacan story.

At that time Kean Santang wawacan was read and sung in beluk. It is identified from forefinger black mark on the lower right edge of the script. It is caused by the frequency of the former opening the manuscript. Kean Santang wawacan manuscripts are loaded with ethnopedagogical values which are primarily based on three categories of human moral practices that related to God (Alloh Swt.), Man, and nature. These three things are implemented in life goals and postulates of Sundanese people i.e. glory, happiness, tranquility and serenity, independence, peace, salvation and perfection of hereafter, physically and spiritually healthy , true, smart, honest, courageous, loving, caring, intellectual, and proportional.

From education view Kean Santang wawacan manuscripts is very feasible as one of the alternative materials of learning nation character education in formal education institutions through the subjects of language, literature, and local culture, especially at schools in West Java.

\section{REFERENCES}

[1] E. S. Ekadjati, Naskah Sunda: Inventarisasi dan Pencatatan. Bandung: Lembaga Penelitian Unpad dan The Toyota Foundation, 1988.

[2] D. Koswara, Sastra Sunda Buhun. Bandung: JPBD FPBS UPI, 2010.

[3] W. Wibisana and Dkk, Lima Abad Sastra Sunda: SebuahAntologi. Jilid I. Bandung: Geger Sunten, 2000.

[4] T. G. Pigeaud, Literature Of Java: Cataloque Raisonne of Javanese Manuscripts in the Library of the University of Leiden and Other Public Collections in the Netherlands. Leiden: The Hague, Martinus Nyhoff, 1968.

[5] S. B. Baried and Dkk, Pengantar Teori Filologi. Jakarta: Pusat Pembinaan dan Pengembangan bahasa, 1985.

[6] E. S. Ekadjati, Cerita Dipati Ukur: Karya Sastra Sejarah Sunda. Jakarta: Pustaka Jaya, 1982.

[7] P. Sardjono, Pengkajian Sastra. Bandung: Yayasan Pustaka, 2005.

[8] R. Stanton, Teori Fiksi: Terjemahan Sugihastuti. Yogyakarta: Pustaka Pelajar, 2007.

[9] A. Teeuw, Sastra dan Ilmu Sastra: Pengantar Teori Sastra. Jakarta: Pustaka Jaya, 1988.

[10] S. Warnaen, Pandangan Hidup Orang Sunda. Bandung: Yayasan Pembangunan Jawa Barat, 1987.

[11] M. Muslich, Pendidikan Karakter: Menjawab Tantangan Krisis Multidimensional. Jakarta: Bumi Aksara, 2011. 
[12] K. Sukanta and Dkk, Nilai-nilai Kearifan Lokal dalam Naskah Sunda Buhun (Wawacan). Bandung: BOPTN UPI, 2011.

[13] Y. Iskandar, Pamanahrasa. Bandung: Yayasan Pembangunan Jawa Barat, 1991.

[14] Y. Iskandar, Putri Subanglarang. Bandung: Yayasan Pembangunan Jawa Barat, 1991.

[15] Y. Iskandar, Prabu Anom Jayadewata. Bandung: Yayasan Pembangunan Jawa Barat, 1996.

[16] Y. Iskandar, Tri Tangtu di Bumi. Bandung: Yayasan Pembangunan Jawa Barat, 1992.

[17] S. Danasasmita, Mencari Gerbang Pakuan. Bandung: Kiblat, 2014.

[18] S. Danasasmita, Menemukan Kerajaan Sunda. Bandung: Kiblat, 2014.

[19] Y. Iskandar, Sejarah Jawa Barat (Yuganing Rajakawasa). Bandung: Geger Sunten, 1997.

[20] K. Saddhono and S. Supeni. "The role of dutch colonialism in the political life of Mataram dynasty: A case study of the manuscript of Babad Tanah Jawi." Asian Soc. Sci. vol. 10 no. 15 pp. $1-7,2014$ 